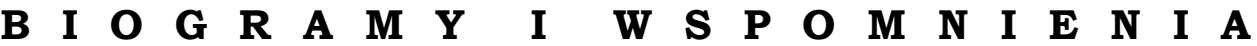

Stanisław Dubisz

DOI: $10.33896 /$ PorJ.2021.8.8

(Towarzystwo Kultury Języka, Warszawa,

e-mail: stdubisz@gmail.com)

ORCID: 0000 0002-4784-5399

\section{PROFESOR TADEUSZ ZGÓŁKA}

26 kwietnia, w wieku 76 lat, zmarł w Poznaniu profesor Tadeusz Zgółka, wybitny językoznawca, podejmujący w swych publikacjach problematykę z zakresu filologii polskiej i językoznawstwa ogólnego, teorii języka, retoryki i pragmalingwistyki, leksykologii i leksykografii, wreszcie filozofii nauki.

Pochodził z dawnych Kresów południowo-wschodnich, urodził się w Rodatyczach - 1 lutego 1945 r. - w Lwowskiem, w 1963 r. zdał egzamin dojrzałości w Liceum Ogólnokształcącym w Rzepinie (dziś województwo lubuskie), studia z zakresu filologii polskiej ukończył na Uniwersytecie im. Adama Mickiewicza w Poznaniu (1968 r.) i tamże podjął pracę asystenta w Katedrze Logiki na Wydziale Filozoficzno-Historycznym. $Z$ uczelnia poznańską był związany przez całe życie poprzez doktorat (1974 r.), habilitacje (1979 r.), docenturę (1981 r.), tytuł naukowy profesora nauk humanistycznych (1991), stanowisko profesora - nadzwyczajnego (1991) i zwyczajnego (1996), wreszcie status profesora seniora (od 2016 r.).

W czasie trwającej 53 lata kariery uniwersyteckiej profesor Tadeusz Zgółka pracował na czterech Wydziałach UAM (Filozoficzno-Historycznym, Filologicznym, Neofilologii, Filologii Polskiej i Klasycznej) i w kilku ich jednostkach (Katedra Logiki, Zakład Metodologii Lingwistyki, Katedra Językoznawstwa Ogólnego i Stosowanego, Zakład Retoryki, Pragmalingwistyki i Dziennikarstwa). Szczególne zasługi położył jako twórca Zakładu Metodologii Lingwistyki, współtwórca oraz pierwszy i wieloletni dziekan Wydziału Neofilologii (1988-1996), kierownik Katedry Językoznawstwa Ogólnego i Stosowanego, inicjator Podyplomowego Studium dla Nauczycieli Języka Polskiego jako Obcego, a także jako projektodawca studiów w zakresie filologii polskiej jako obcej w Collegium Polonicum w Słubicach.

Profesor Tadeusz Zgółka za swego mistrza naukowego uznawał prof. dra hab. Jerzego Kmitę - logika i metodologa nauki, twórce teorii historii nauki pojętej jako dziedzina kultury - pod którego kierunkiem opracował w 1974 r. dysertację doktorska pt. Wyjaśnianie faktów językowych zakładane przez praska szkołę strukturalna (wyd. książowe: O strukturalnym wyjaśnianiu faktów językowych, PWN, Warszawa-Poznań 1976). W tym samym interdyscyplinarnym nurcie metodologicznym sytuuje się również jego rozprawa habilitacyjna (1979) pt. Język. Kompetencja. Gramatyka. Studium z metodologii lingwistyki 
(wyd. PWN, Warszawa - Poznań 1980). Oprócz tych pozycji dorobek naukowy profesora Tadeusza Zgółki obejmuje osiem publikacji książkowych (w tym pięć współautorskich), około 130 artykułów, redakcje tomów zbiorowych, prace leksykograficzne i encyklopedyczne oraz kilkanaście recenzji. Jest to dorobek obszerny, wielowątkowy, interdyscyplinarny, mający zasięg międzynarodowy. $Z$ publikacji książkowych można tu przykładowo wymienić Język wśród wartości (1988), Językowy savoir-vivre (wraz z Halina Zgółkowa, 1992 i in.), Słownictwo współczesnej poezji polskiej. Listy frekwencyjne (wraz z Halina Zgółkowa, 1992), a $z$ artykułów np. Eksplikacja pojęcia systemu w koncepcjach fonologicznej szkoły praskiej (1975), O teoretycznych podstawach tzw. polityki językowej (1981), Psychologizm a społeczny charakter języka w koncepcjach lingwistycznych J.N. Baudouina de Courtenay (1989), Tekstowe, funkcjonalne i pragmatyczne kryteria wyodrębniania stylowych odmian języka (1991), Warstwy świadomości językowej (1996), Kształtowanie sprawności i umiejętności w zakresie nauczania języka polskiego jako obcego (1997), Pośrednie akty mowy w retoryce współczesnej (2001), Retoryka tabuizacji (2009), Retoryka a kultura języka (2017).

Przedstawiony wyżej skromny „wyciag” $z$ bibliografii prac autorstwa profesora Tadeusza Zgółki ma - oczywiście - charakter subiektywny i nie jest jego celem dokonanie charakterystyki tego dorobku naukowego. Chodziło w tym wypadku o zasygnalizowanie części zakresów zainteresowań naukowych ich Autora, które w sposób szczególny wywarły wpływ na pracę naukowa piszacego te słowa. $Z$ tej też przyczyny nie sposób nie wspomnieć ponaddziesięcioletniej pracy leksykograficznej profesora Tadeusza Zgółki jako zastępcy redaktora naukowego i współautora Praktycznego słownika współczesnej polszczyzny (1994-2005, t. 1-50) pod redakcja naukową Haliny Zgółkowej oraz jako współprzewodniczącego Wydawniczej Rady Naukowej i autora wybranych haseł polskiej edycji Encyklopedii Britannica (1997-2005, t. 1-49).

Trzeba w tym miejscu podkreślić, że profesor Tadeusz Zgółka publikował również w „Poradniku Językowym”. Jego ostatnie artykuły ukazały się w 2018 r. - Rozterki praktykujacego słownikarza. Esej leksykograficzny (PorJ 2018, z. 4, s. 21-27); Leksykalna kategoryzacja rzeczywistości w słownikach ostatniego stulecia polskiej leksykografii (wraz z. H. Zgółkowa, PorJ 2018, z. 8, s. 40-51).

Naukowców można (oprócz klasyfikacji innych) podzielić na „gabinetowych” i „uspołecznionych”. Ci pierwsi nie wykraczaja poza sferę twórczości naukowej, ci drudzy - poza tą twórczościa - wykonuja inne prace na rzecz środowiska naukowego, instytucji naukowych i społecznych. $Z$ dotychczasowych uwag, poczynionych w tym wspomnieniu, wynika jednoznacznie, że profesor Tadeusz Zgółka był językoznawca uspołecznionym. Świadcza o tym liczne prace organizacyjne na rzecz Uniwersytetu im. Adama Mickiewicza i funkcje tam pełnione (o których już była mowa), a także inne zakresy jego działalności. Wchodził w skład Państwowej Komisji Poświadczania Znajomości Języka Polskiego jako Obcego (2003-2016), Komitetu Językoznawstwa PAN (2004-2010), Rady Języka Polskiego przy Prezydium PAN (od 2004 r., od 2019 r. wiceprzewodniczacy), był także członkiem rzeczywistym Wydziału Filologiczno-Filozoficznego Poznańskiego Towarzystwa Przyjaciół Nauk.

Charakter działalności pracownika akademickiego wyższej uczelni w Polsce wymaga, by wypełniał swe obowiazki w trzech sferach: naukowej, dydaktycz- 
nej i organizatorskiej. O profesorze Tadeuszu Zgółce można powiedzieć, że we wszystkich tych zakresach osiagnął poziom mistrzowski.

Jak to w środowisku naukowym bywa, najpierw znaliśmy się skądinąd - $z$ konferencji, przewodów naukowych, konwentykli towarzyskich - ale bliższy stopień znajomości i zażyłości osiagnęliśmy na początku lat 90. ubiegłego już wieku, kiedy to niejako „asystowaliśmy” profesorowi Stanisławowi Gajdzie przy tworzeniu zrębów ogólnopolskiego projektu badawczego „Przemiany współczesnej polszczyzny (1945-1995)”. Owa zażyłość przerodziła się szybko we współpracę zespołu badawczego kierowanego przez profesor Halinę Zgółkowa ( $z$ aktywnym udziałem Tadeusza) i zespołu badawczego Pracowni Językoznawstwa Stosowanego UW pod moim kierunkiem, która trwała kilka lat w formie bilateralnych sympozjów odbywanych na przemian w Poznaniu i w Warszawie. W czasie tych spotkań ujawniły się w pełni rozliczne zalety intelektualne i talenty Tadeusza - olbrzymia erudycja, znajomość realiów humanistyki polskiej, umiejętność prowadzenia dyskursu i błyskotliwej riposty, żarliwość, wręcz nieustępliwość, w debacie, talenty retoryczne i erystyczne.

Zażyłość ta była podtrzymywana przez stałe kontakty związane ze współpraca leksykograficzna, $z$ udziałem w pracach komisji certyfikacyjnej, Komitetu Językoznawstwa PAN, Rady Języka Polskiego, z przewodami doktorskimi i habilitacyjnymi, z publikacjami, wreszcie ze spotkaniami okolicznościowymi.

Tadeusz bywał w Warszawie często, ja w Poznaniu rzadziej, ale spotykaliśmy się przecież w różnych miejscach i w różnych sytuacjach, że przypomnę nadmiernie długo trwajaca (ze względu na zatory drogowe) podróż $z$ Rzeszowa do Warszawy z VIII Forum Kultury Słowa (październik 2011). Podczas spotkań prywatnych, nieformalnych Tadeusz bywał duszą towarzystwa, błyszczał dowcipem, elegancją i humorem. Bywało, że żartobliwie licytowaliśmy się (w zwiazku $z$ podobieństwem niektórych aspektów naszych dróg uniwersyteckich) co do naszych osiagnięć - ja wygrywałem pod względem długości kadencji dziekańskich, On pod względem liczby wypromowanych doktorów.

Tadeusz był człowiekiem słownym i spolegliwym, we współpracy naukowej i dydaktycznej rzetelnym, w kontaktach osobistych - szczerym i życzliwym. W naszych wzajemnych kontaktach doświadczyliśmy swej spolegliwości wielokrotnie. Był wreszcie Tadeusz - jak to się potocznie mówi - mężem swojej żony pani profesor Haliny Zgółkowej, a jak On sam mawiał „Zgółczyny”, z która stanowił parę życiowa i intelektualna znana w całym polskim (i nie tylko) środowisku językoznawczym. Ostatni raz spotkałem się z Nimi Obojgiem w Poznaniu właśnie na Jej jubileuszu i nie przyszło mi nawet na myśl, że $z$ Tadeuszem może to być spotkanie ostatnie.

Profesor Tadeusz Zgółka często na powitanie wygłaszał formułę Bądź pozdrowiony. Pozostaje pożegnać go w tym duchu - Vale! Omnia mutantur, nihil interit. 